\title{
Cycle duration and quality of gladiolus floral stems in three locations of Southern Brazil ${ }^{(1)}$
}

\author{
REGINA TOMIOZZO(2)*, GIZELLI MOIANO DE PAULA ${ }^{(3)}$, NEREU AUGUSTO STRECK ${ }^{(2)}$, \\ LILIAN OSMARI UHLMANN(2), CAMILA COELHO BECKER(2), NATALIA TEIXEIRA SCHWAB(2), \\ MARTINA MUTTONI(4), CLEBER MAUS ALBERTO(4)
}

\begin{abstract}
The objective of this study was to determine the cycle duration in days and the quantitative parameters, i.e. stem length, spike length and stem diameter of gladiolus floral stems as a function of the planting date and locations in the Rio Grande do Sul/Brazil. Field experiments were established between 2014-2015 in three locations (Frederico Westphalen, Itaqui and Santa Maria). The experimental design was a complete randomized block, with six gladiolus cultivars in three distinct planting dates at each location as treatments. The shift from vegetative to reproductive stage, the stem length, spike length and stem diameter were evaluated. Data was statistically analyzed by ANOVA and Tukey test. When planted during late July and early August, cultivars of early cycle ('Purple Flora', 'Rose Friendship' and 'White Friendship') and intermediate cycle ('Green Star' and 'Jester'), produced floral stems of gladiolus in the desired patterns besides as well as having a shorter growth cycle than late cultivars ('Gold Field'), being recommended for commercial cultivation in Southern Brazil.
\end{abstract}

Keywords: Gladiolus $x$ grandiflorus Hort., growing local, planting date, stem quality.

\section{RESUMO}

Duração do ciclo e qualidade das hastes florais de gladíolo em três locais do Sul do Brasil

O objetivo neste estudo foi determinar a duração do ciclo em dias e os parâmetros quantitativos de hastes florais de gladíolo em função da data de plantio e do local de cultivo no Rio Grande do Sul/Brasil. Experimentos de campo foram estabelecidos entre 20142015 em três locais (Frederico Westphalen, Itaqui e Santa Maria). O delineamento experimental foi o de blocos completamente casualizados, com seis cultivares de gladíolo em três diferentes datas de plantio em cada local como tratamento. Foram avaliadas a mudança do estágio vegetativo para o reprodutivo, o comprimento da haste, comprimento da espiga e diâmetro da haste no ponto de colheita. Os dados foram analisados estatisticamente pela ANOVA e pelo teste de Tukey. Quando plantadas durante o final de julho e início de agosto, cultivares de ciclo precoce ('Purple Flora', 'Rose Friendship' e 'White Friendship') e intermediário ('Green Star' e 'Jester') produzem hastes florais de gladíolo dentro dos padrões desejados, além de possuir um menor ciclo de crescimento do que cultivares tardias ('Gold Field'), sendo recomendadas para cultivo comercial no Sul do Brasil.

Palavras-chave: Gladiolus x grandiflorus Hort., local de cultivo, data de plantio, qualidade de haste.

\section{INTRODUCTION}

Gladiolus (Gladiolus $x$ grandiflorus Hort.), is an ornamental crop with spike-like inflorescences (floral stems) (STRECK et al., 2012; SCHWAB et al., 2015a). The major market of gladiolus is as a cut flower, but it is also used in landscaping, events ornamentation and special dates. It is a flower that attracts the attention of the people by its spectacular flowers that present a wide range of colors and sizes (ZUBAIR et al., 2006). The colors most acceptable to consumers are white $(40 \%)$, red $(25 \%)$, yellow $(12 \%)$, rose $(10 \%)$, coral $(10 \%)$ and purple (10\%) (TOMBOLATO et al., 2010). It ranks eighth in the world flower trade (AHMAD et al., 2008) and in Brazil the majority of gladiolus sales occurs at All Soul's Day (SCHWAB et al., 2015b).
Meteorological conditions during the growth season affect the development and quality of the gladiolus floral stems (SCHWAB et al., 2015b). The developmental phase, from planting $(\mathrm{PL})$ to harvest point [R2 stage, when the first three floral buds show the corolla color, (SCHWAB et al., 2015a)], changes with variations in air temperature (STRECK et al., 2012; VASANTHAKUMAR et al., 2015; SCHWAB et al., 2015b). Gladiolus grows better in mild climate, preferring temperatures between 10 and $25^{\circ} \mathrm{C}$ (INTERNATIONAL FLOWER BULB CENTER, 2011). However, plants are capable of tolerating temperatures up to $50{ }^{\circ} \mathrm{C}$ during the vegetative development (LIM, 2014; SHILLO and HAVELY, 1976c) and florets can be damaged by frost (SCHWAB et al., 2015b). Other environmental variables such as air humidity and light intensity may also influence gladiolus growth and

DOI: http://dx.doi.org/10.14295/oh.v24i4.1237

${ }^{(1)}$ Received in 05/06/2018 and accepted in 25/09/2018

${ }^{(2)}$ Federal University of Santa Maria (UFSM), Crop Science Departament, Santa Maria-RS, Brazil. *Corresponding author: re.tomiozzo@gmail.com

${ }^{(3)}$ Federal University of Santa Maria (UFSM), Campus Frederico Westphalen, Agronomic and Enviromental Science Departament, Frederico Westphalen-RS, Brazil.

${ }^{(4)}$ Federal University of Pampa (UNIPAMPA), Campus Itaqui, Itaqui-RS, Brazil.

Licensed by CC BY 4.0 
development (SHILLO and HAVELY, 1976a, b, c, d; ADIL, et al. 2013).

The 'Veiling Holambra', a chief cooperative in Brazil which deals in flower sales categorizes them based on quality, which includes both qualitative and quantitative parameters (VEILING HOLAMBRA, 2016). The qualitative or non measurable parameters refer to mild or severe damage resulting from sunburn, insects or diseases (TOMBOLATO et al., 2010; SCHWAB et al., 2015b; VEILING HOLAMBRA, 2016). On the other hand, the quantitative or measurable parameters for gladiolus include total stem length (peduncle + inflorescence), stem diameter and spike length (inflorescence) (SCHWAB et al., 2015b; VEILING HOLAMBRA, 2016). Flowers that fall below these standards are considered as non-marketable. The florets open in sequence over a longer duration (DWIVEDI et al., 2016) and a bigger spike length with more florets will provide vase life longevity.

The grower must plan the growth duration to ensure that the floral stems are harvested during the period of greatest market demand. However, because each gladiolus cultivars varies with respect to the developmental cycle length, the date and location of cultivation can also influence the quantitative parameters of the floral stems. In previous studies on gladiolus, Streck et al. (2012) and Schwab et al. $(2015 a, b)$ conducted a research on the effect of the planting date on the developmental cycle in the Central Region of the Rio Grande do Sul State, using monthly planting dates on several cultivars, however they didn't evaluated the quality parameters. Furthermore, their studies should be extended to locations across the State, which varies in climate and soil.

The objective of this study was to determine the cycle duration in days and the quantitative parameters, i.e. stem length, spike length and stem diameter of gladiolus floral stems as a function of the planting date and locations in the Rio Grande do Sul/Brazil.

\section{MATERIAL AND METHODS}

Field experiments were conducted between 2014-2015 at three sites in Rio Grande do Sul State/Brazil (Figure 1): Frederico Westphalen (latitude: $27^{\circ} 23^{\prime} 45^{\prime \prime} \mathrm{S}$, longitude: $53^{\circ} 25^{\prime} 46^{\prime \prime} \mathrm{W}$, and altitude: $489 \mathrm{~m}$ ), Itaqui (latitude: $29^{\circ}$ 07' 10"S, longitude: $56^{\circ} 32^{\prime} 32^{\prime} \mathrm{W}$, and altitude: $50 \mathrm{~m}$ ), and Santa Maria (latitude: $29^{\circ} 43^{\prime} \mathrm{S}$, longitude: $53^{\circ} 43^{\prime} \mathrm{W}$, and altitude: $95 \mathrm{~m}$ ). These three sites differed in soil and climatic conditions. At Frederico Westphalen, the mean annual temperature is $18{ }^{\circ} \mathrm{C}$, while at Itaqui it is $20^{\circ} \mathrm{C}$ and Santa Maria $19{ }^{\circ} \mathrm{C}$. The soil at Frederico Westphalen is a Red Dystrophic Latosol, whereas at Itaqui it is a Hapless Plinthol. In Santa Maria, the soil is a transition between Arsenic dystrophic Red Argisol and a typical Argiluvic Hypochromic Alisol (STRECK et al., 2008).

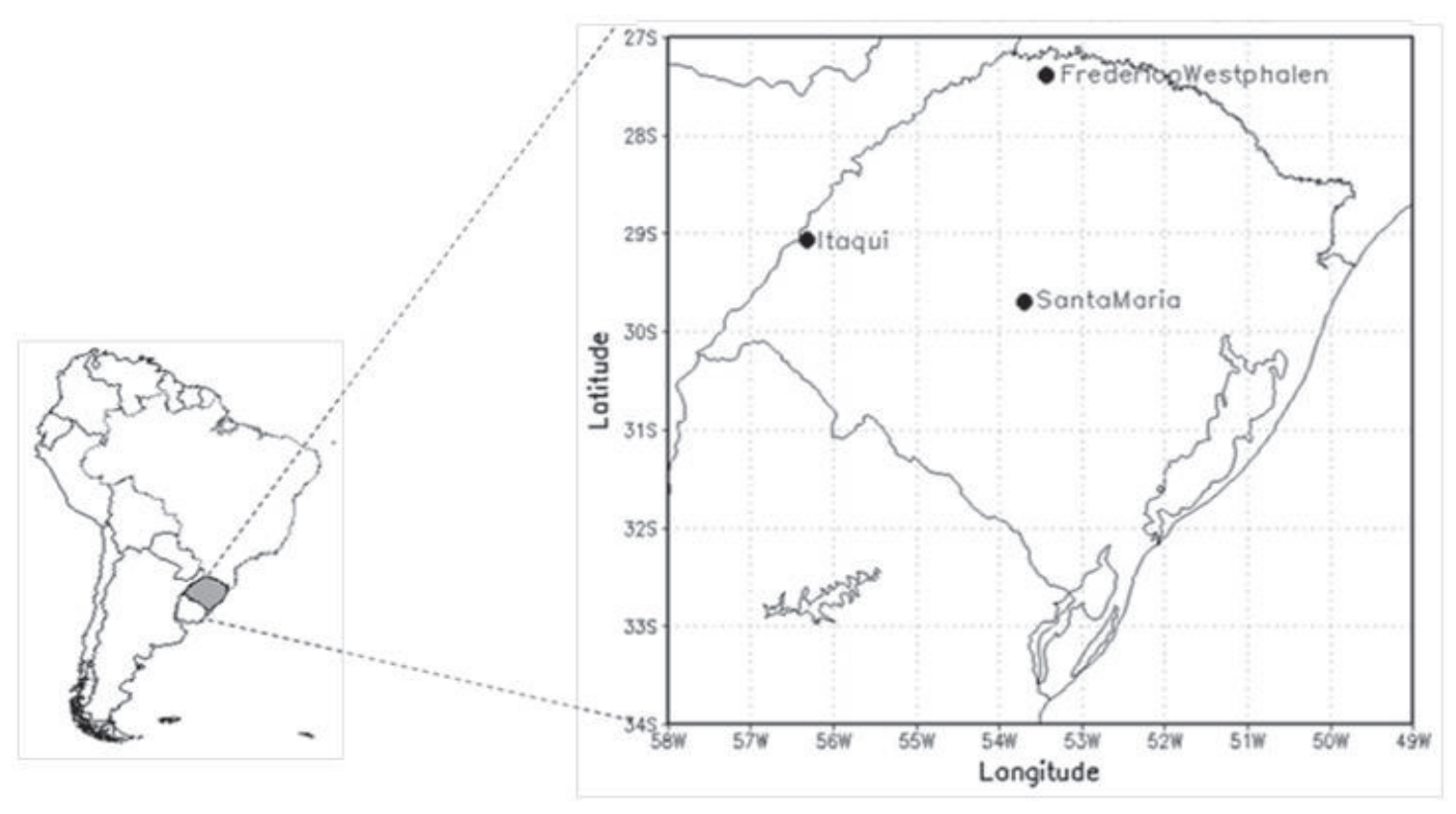

(a)

(b)

Figure 1. Map of South America (a) and Rio Grande do Sul State/Brazil state (b) with the sites of the experiments with gladiolus (Frederico Westphalen, Itaqui and Santa Maria). 
In each site, the experiment was conducted in a randomized block design, with four replications of the selected cultivars. Each plot (replication) having ten plants, arranged in two paired lines, of which the six central plants were evaluated, with the four lateral plants used as border plants. A joint analysis was performed considering a three-way factorial experiment. Factor A was cultivars as six levels: 'Purple Flora' (early cycle, purple florets), 'White Friendship' (early cycle, white florets), 'Rose Friendship' (early cycle, pink florets), 'Green Star' (intermediate cycle, green florets), 'Jester' (intermediate cycle, yellow florets with red interiors) and 'Gold Field' (late cycle, yellow florets) (UHLMANN et al., 2017). Factor B was the cultivation site, shown in three levels by the cities of Frederico Westphalen, Itaqui and Santa Maria. Factor C represented by the planting date arranged in three levels, separated by 30 to 45 days, that varied upon the site: in Frederico Westphalen had experiments started on 08/05/2014, 08/29/2014 and 10/23/2014; in Itaqui planting were on $07 / 28 / 2014$,
09/22/2014 and 10/26/2014, and in Santa Maria on 07/31/2014, 09/23/2014 and 10/27/2014.

In each planting date, two beds of $15 \mathrm{~cm}$ in height, $17 \mathrm{~m}$ in length and $1 \mathrm{~m}$ in width were used, with two replications per cultivar in each bed (Figure 2a). Each flowerbed had two paired rows with $40 \mathrm{~cm}$ between the rows and $20 \mathrm{~cm}$ between the plants. Commercial vernalized corms, 14-16 $\mathrm{cm}$ in diameter were used. Fertilization was performed using commercial fertilizer $05-20-20$, in varying quantities based on the soil tests at each site; nitrogen fertilization was also provided with urea as a side dress at a $350 \mathrm{~kg}$ $\mathrm{ha}^{-1}$ rate $(45 \% \mathrm{~N})$ at the $\mathrm{V} 3-\mathrm{V} 4$ stage (Figure $\left.2 \mathrm{~b}\right)$, when the spike was differentiating (SCHWAB et al., 2015a). At the flag leaf stage (VF), plants were supported vertically with plastic wires fixed on bamboo stakes. Beyond the rain, in Santa Maria, plants were irrigated with a drip irrigation system whereas in Frederico Westphalen and Itaqui experiments were irrigated by manual irrigation with watering cans. The irrigation was performed according to the water requirement of the plant. a)
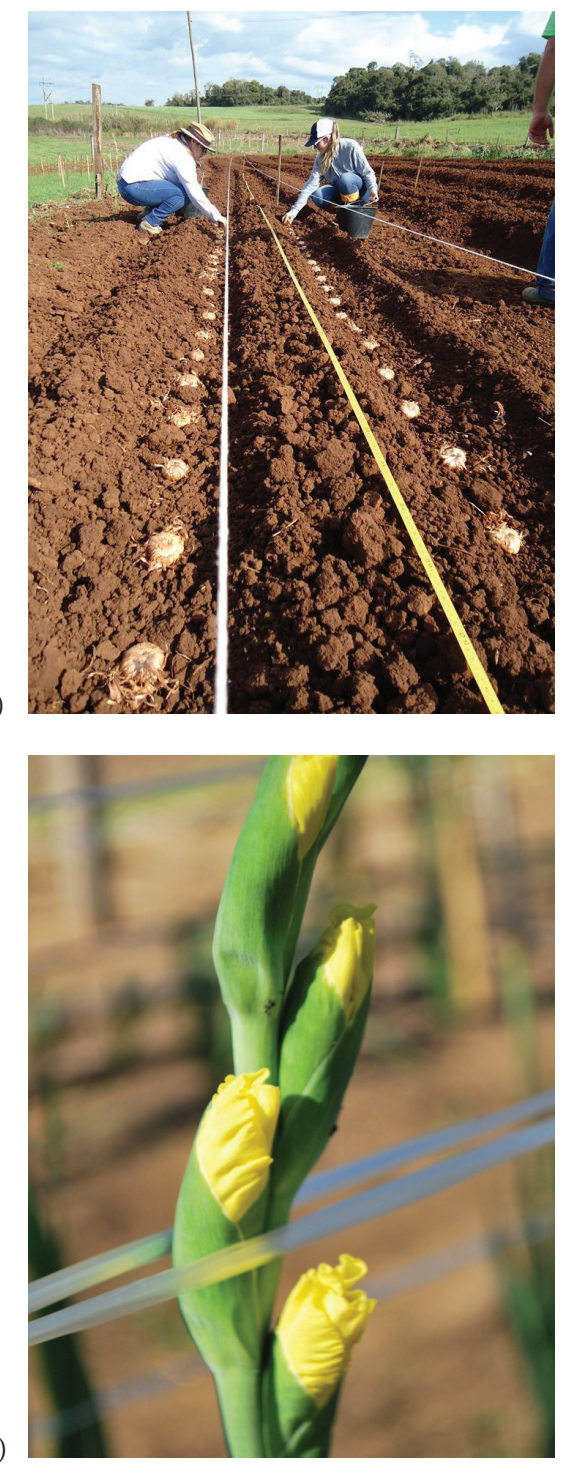
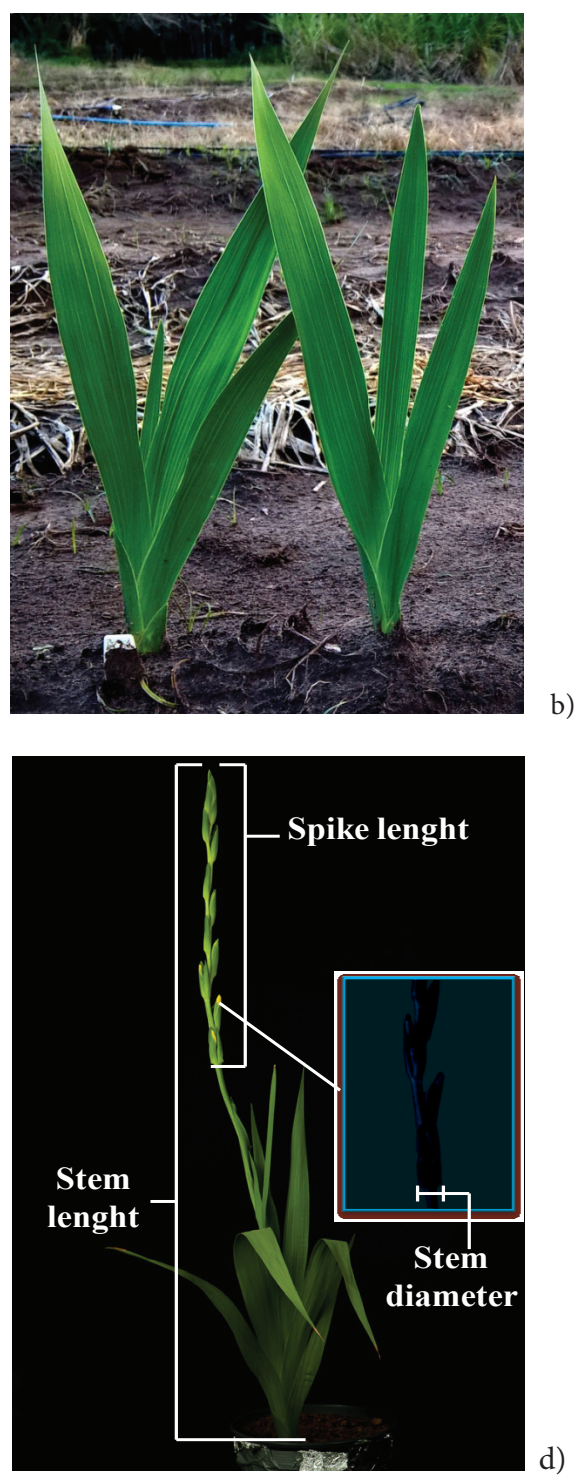

Figure 2. Main development stages of gladiolus: planting (a), V3-V4 stage (b), R2 stage (c) and description of: the quantitative parameters (d). 
The harvest point (R2) it was considered as the day on which the first three florets at the bottom of the spike showed the color of the corolla (Figure 2c) (SCHWAB et al., 2015a). The parameters stem length (peduncle + inflorescence), spike length and stem diameter just below the insertion point of the first leaf were measured at R2 (Figure 2d). The stem length was considered as the distance from the plant at soil surface level to the spike tip and the spike length was the distance between the insertion of the first leaf to the spike tip (SCHWAB et al., 2015b).

Stems were grouped in to three classes based on the criteria proposed by the Veiling Holambra cooperative: Class 75 - stem length of $75 \mathrm{~cm}$ with $0.5 \mathrm{~cm}$ minimum diameter; Class $90-$ stem length of $90 \mathrm{~cm}$ with minimum diameter $0.8 \mathrm{~cm}$; and Class 110 - stem length of $110 \mathrm{~cm}$ with minimum diameter of $1.10 \mathrm{~cm}$ (VEILING HOLAMBRA, 2016). The spike length must exhibit a minimum of $40 \%$ of the stem length (VEILING HOLAMBRA, 2016). Floral stems that are shorter than $75 \mathrm{~cm}$ or exhibiting a minimum diameter less than the established value for each class were considered non-marketable.
The minimum and maximum air temperatures and precipitation data were recorded on a daily basis at the three sites with automatic weather stations located near the experimental sites. Data was statistically analysed by ANOVA and Tukey's test $(p<0.05)$.

\section{RESULTS AND DISCUSSION}

The different cultivation sites and planting dates exposed gladiolus plant to distinct environmental conditions. The sites showed absolute air temperature variations from 1 to $36{ }^{\circ} \mathrm{C}, 4$ to $37{ }^{\circ} \mathrm{C}$ and 0 to 38 ${ }^{\circ} \mathrm{C}$, at Frederico Westphalen, Itaqui and Santa Maria, respectively (Figure 3). The accumulated average rainfall from planting to R2 was $864 \mathrm{~mm}, 961 \mathrm{~mm}$ and $1218 \mathrm{~mm}$ for Frederico Westphalen, Itaqui and Santa Maria, respectively. Even with the high precipitation according to the climatological normal of the period, additional irrigations were carried out, especially for the last planting date in three sites.
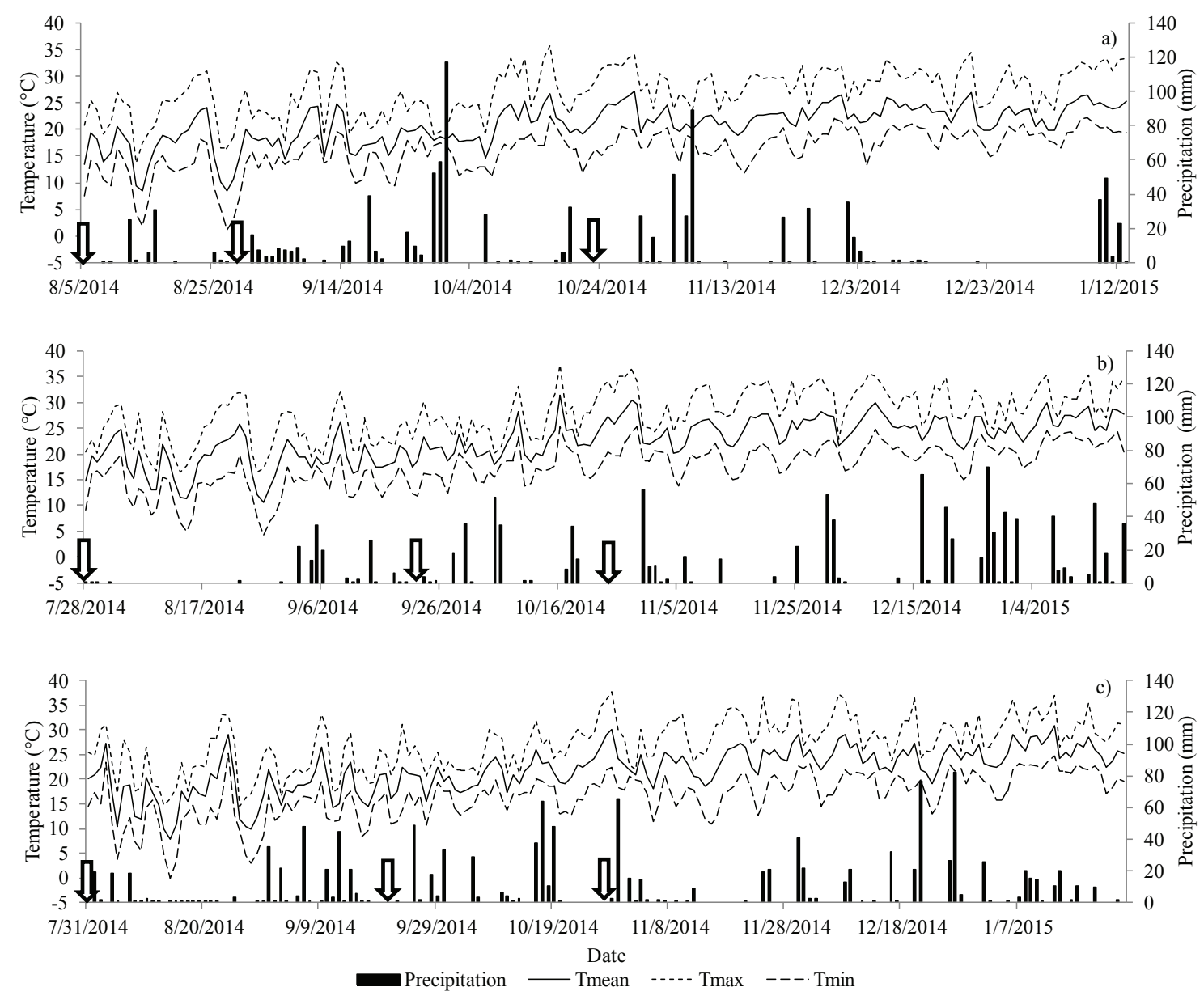

Figure 3. Daily variations in minimum (Tmin), mean (Tmean) and maximum (Tmax)

air temperatures $\left({ }^{\circ} \mathrm{C}\right.$ ) and precipitation $(\mathrm{mm})$ in Frederico Westphalen (a), Itaqui (b) and Santa Maria (c). The arrows indicate the planting dates in the sites ( $\mathrm{mm} / \mathrm{dd} / \mathrm{yyyy})$. 
For the variables growth duration (days) of the PL-R2 phase $\left(C V=2.68 \%, R^{2}=0.95\right)$, stem length $(C V=28 \%$, $\left.\mathrm{R}^{2}=0.88\right)$, spike length $\left(\mathrm{CV}=7.44 \%, \mathrm{R}^{2}=0.84\right)$, and stem diameter $\left(\mathrm{CV}=5.25 \%, \mathrm{R}^{2}=0.77\right)$, there was a significant three-way interaction among the studied cultivars, cultivation site and planting date.

The 'Gold Field' cultivar showed the lowest floral stem length (Table 2) and stem length (Table 3) in Frederico Westphalen during the first $(35.6$ and $104.4 \mathrm{~cm})$ and the second planting dates $(34.5$ and $98.9 \mathrm{~cm})$, respectively, and increased length of PL-R2 (Table 1), revealing 85.3 days for the first planting date and 84.7 days for the second. The 'Gold Field' cultivar exhibited spike lengths below the minimum standards established for commercialization in terms of the spike length, which failed to attain a minimum of $40 \%$ of the stem length. A long duration of the PL-R2 phase also is not desirable because the plants would be exposed to biotic and abiotic, diseases and damages for a longer time (SALEEM et al., 2013) which can result in a decrease in the number of florets and stem length (SEVERINO, 2007), besides affecting the qualitative stem parameters.

Table 1. Average duration (days) from planting to harvest point (PL-R2) of the six gladiolus cultivars for three planting dates $(\mathrm{mm} / \mathrm{dd})$ in three locations in Rio Grande do Sul/Brazil: Frederico Westphalen (FW), Itaqui (IT) and Santa Maria (SM) in 2014.

\begin{tabular}{|c|c|c|c|c|c|c|c|}
\hline \multirow[b]{2}{*}{ Site } & \multirow[b]{2}{*}{$\begin{array}{c}\text { Planting } \\
\text { date }\end{array}$} & \multicolumn{6}{|c|}{ Cultivars } \\
\hline & & Gold Field & Green Star & Jester & $\begin{array}{c}\text { Purple } \\
\text { Flora }\end{array}$ & $\begin{array}{c}\text { Ros } \\
\text { Friendship }\end{array}$ & $\begin{array}{c}\text { White } \\
\text { Friendship }\end{array}$ \\
\hline & 08/05 & $85.3 \mathrm{Aa} A^{(1)}$ & 80.7Аa $A$ & 83.6Аa $A$ & $73.4 \mathrm{Ba} A$ & $72.2 \mathrm{Ba} A$ & $72.2 \mathrm{Ba} A$ \\
\hline \multirow[t]{3}{*}{ FW } & $08 / 29$ & 84.7Аa $A$ & $78.1 \mathrm{Ba} B$ & 79.9ABa $A$ & $66.8 \mathrm{Cb} A$ & $63.8 \mathrm{Cb} A$ & $65.5 \mathrm{Cb} A$ \\
\hline & $10 / 23$ & $-(2)$ & $82.5 \mathrm{Aa} A$ & $83.3 \mathrm{Aa} A$ & $74.7 \mathrm{Ba} A$ & $75.8 \mathrm{Ba} A$ & $75.2 \mathrm{Ba} A$ \\
\hline & $07 / 28$ & 88.1Aa $A$ & $81.6 \mathrm{BCa} A$ & $85.5 \mathrm{ABa} A$ & 77.0CDa $A$ & $75.3 \mathrm{Da} A$ & $72.9 \mathrm{Da} A$ \\
\hline \multirow[t]{3}{*}{ IT } & $09 / 22$ & $90.1 \mathrm{Aa} A$ & $84.5 \mathrm{ABa} A$ & $84.0 \mathrm{Ba} A$ & $69.1 \mathrm{Cb} A$ & $69.2 \mathrm{Cb} A$ & $66.6 \mathrm{Cb} A$ \\
\hline & $10 / 26$ & $90.9 \mathrm{Aa} A$ & 87.4Aa $A$ & $86.0 \mathrm{Aa} A$ & 71.6Bab $A B$ & 74.0Bab $A$ & 69.3Bab $A B$ \\
\hline & $07 / 31$ & $91.2 \mathrm{Aa} A$ & $84.9 \mathrm{Ba} A$ & $88.3 \mathrm{ABa} A$ & $78.6 \mathrm{Ca} A$ & $76.8 \mathrm{Ca} A$ & $75.3 \mathrm{Ca} A$ \\
\hline \multirow[t]{2}{*}{ SM } & $09 / 23$ & 86.1Aa $A$ & $76.1 \mathrm{Bb} B$ & $78.1 \mathrm{Ba} A$ & $69.8 \mathrm{Cb} A$ & $68.4 \mathrm{Cb} A$ & $67.0 \mathrm{Cb} A$ \\
\hline & $10 / 27$ & $85.4 \mathrm{Aa} A$ & 80.9ABab $A$ & $77.3 \mathrm{Bb} B$ & $66.8 \mathrm{Cb} B$ & $71.2 \mathrm{Cab} A$ & $66.5 \mathrm{Cb} B$ \\
\hline
\end{tabular}

(1) Upper case letters indicate a comparison of the various cultivars in the row within each planting date for each site. Lower case letters enable the comparison of the cultivars in the column, at the planting dates, in each site. Italic upper case letters compare the same cultivar in the column, on the same planting date of the cultivars at the three different locations. Means followed by the same letter do not differ according to the Tukey test at $5 \%$ error. $\mathrm{CV}=2,68 \%$.

${ }^{(2)}$ No data are available for this cultivar on this planting date and cultivation site.

In general, the 'Gold Field' cultivar had the longest PLR2 phase, which was confirmed at the other two sites as well (Table 1); however, there was increase in stem length and spike length only for Santa Maria on the second and third planting dates when compared with the other sites. Despite such an increase in the stem lengths, the 'Gold Field' cultivar has fallen below the commercial standards. The 'Jester' (35.1 cm), 'Rose Friendship' (35.7 cm) and 'White Friendship' $(41.0 \mathrm{~cm})$ showed the shortest spike length on the third planting date in Frederico Westphalen (Table 2). While 'Green Star' $(98.7 \mathrm{~cm})$ and 'Purple Flora' $(88.7 \mathrm{~cm})$ also revealed the shortest stem length at the third planting date in Frederico Westphalen (Table 3). The spike has a direct bearing on the stem length of the plant (ALBUQUERQUE et al., 2010), because as the length varies, the spike length also changes, implying that shorter stems will bear shorter floral banners.

No difference regarding the spike length was observed for the 'Purple Flora' at all the three planting dates in Itaqui (Table 2). 'Green Star', 'Jester', 'Rose Friendship' and 'White Friendship' cultivars recorded the longest stem lengths on the first planting date. While 'Green Star' showed no difference in the second planting date and 'Jester' showed no change at the third one. However, for the stem length (Table 3), the largest length occurred on the first planting date in Itaqui for early and intermediate cycle cultivars, and only 'Jester' cultivar did not differ from the third planting date. The 'Green Star', 'Jester' and 'White Friendship' cultivars also showed similar results with respect to stem diameter (Table 4), except for the 'Gold Field', 'Purple Flora' and 'Rose Friendship' cultivars, which revealed no difference for all the planting dates in Itaqui. The combination of long stems and higher diameters are desirable features because they provide stems with greater degree of stiffness raising their postharvest durability, allowing longer periods of sale (ALBUQUERQUE et al., 2010; SCHWAB et al., 2015b). 
Table 2. Spike length $(\mathrm{cm})$ of the six gladiolus cultivars for the three planting dates $(\mathrm{mm} / \mathrm{dd})$ in three locations in Rio Grande do Sul/Brazil: Frederico Westphalen (FW), Itaqui (IT) and Santa Maria (SM) in 2014.

\begin{tabular}{|c|c|c|c|c|c|c|c|}
\hline \multirow{2}{*}{ Site } & $\begin{array}{c}\text { Planting } \\
\text { date }\end{array}$ & Gold Field & Green Star & Jester & $\begin{array}{c}\text { Purple } \\
\text { Flora }\end{array}$ & $\begin{array}{c}\text { Rose } \\
\text { Friendship } \\
\text { Friendship }\end{array}$ \\
\hline & $08 / 05$ & $35.6 \mathrm{Ba} A^{(1)}$ & $48.9 \mathrm{Aa} A$ & $50.6 \mathrm{Aa} A$ & $48.4 \mathrm{Aa} A$ & $47.5 \mathrm{Aa} A$ & $53.9 \mathrm{Aa} A$ \\
\hline & $08 / 29$ & $34.5 \mathrm{Ba} B$ & $48.3 \mathrm{Aa} A$ & $48.3 \mathrm{Aa} A B$ & $45.7 \mathrm{Aa} A$ & $45.1 \mathrm{Aab} A$ & $51.5 \mathrm{Aa} A$ \\
\hline & $10 / 23$ & $-(2)$ & $51.5 \mathrm{Aa} A$ & $35.1 \mathrm{Ab} B$ & $39.3 \mathrm{Aa} A$ & $35.7 \mathrm{Ab} A$ & $41.0 \mathrm{Ab} A$ \\
\hline & $07 / 28$ & $39.8 \mathrm{Ca} A$ & $50.4 \mathrm{Ba} A$ & $51.2 \mathrm{Ba} A$ & $48.4 \mathrm{BCa} A$ & $51.7 \mathrm{ABa} A$ & $61.1 \mathrm{Aa} A$ \\
\hline & $09 / 22$ & $35.4 \mathrm{ABa} B$ & $43.2 \mathrm{Aab} A$ & $40.5 \mathrm{ABb} B$ & $40.3 \mathrm{ABa} A$ & $32.6 \mathrm{Bb} B$ & $33.8 \mathrm{ABc} B$ \\
\hline & $10 / 26$ & $38.7 \mathrm{Aa} A$ & $37.5 \mathrm{Ab} A$ & $44.2 \mathrm{Aab} A B$ & $41.2 \mathrm{Aa} A$ & $38 . \mathrm{Ab} A$ & $43.8 \mathrm{Ab} A$ \\
\hline & $07 / 31$ & $39.7 \mathrm{Ca} A$ & $53.9 \mathrm{Aa} A$ & $53.6 \mathrm{ABa} A$ & $49.5 \mathrm{Ba} A$ & $53.6 \mathrm{ABa} A$ & $60.2 \mathrm{Aa} A$ \\
\hline & $09 / 23$ & $47.9 \mathrm{Aa} A$ & $51.3 \mathrm{Aa} A$ & $52.7 \mathrm{Aa} A$ & $47.0 \mathrm{Aa} A$ & $43.8 \mathrm{Aab} A$ & $47.9 \mathrm{Ab} A$ \\
\hline & $10 / 27$ & $44.0 \mathrm{Aa} A$ & $46.7 \mathrm{Aa} A$ & $45.9 \mathrm{Aa} A$ & $47.5 \mathrm{Aa} A$ & $40.1 \mathrm{Ab} A$ & $49.7 \mathrm{Ab} A$ \\
\hline
\end{tabular}

(1) Upper case letters indicate a comparison of the various cultivars in the row within each planting date for each site. Lower case letters enable the comparison of the cultivars in the column, at the planting dates, in each site. Italic upper case letters compare the same cultivar in the column, on the same planting date of the cultivars at the three different locations. Means followed by the same letter do not differ according to the Tukey test at $5 \%$ error. $\mathrm{CV}=7,44 \%$.

${ }^{(2)}$ No data are available for this cultivar on this planting date and cultivation site.

The three cultivars, 'Green Star', 'Jester' and 'Purple Flora' showed no difference in the spike length (Table 2) and stem length (Table 3 ) for all the three planting dates in Santa Maria. The 'Rose Friendship' and 'White Friendship' cultivars revealed the longest lengths, for both total lengths of spike and stem for the first planting date in Santa Maria, with no difference in the second planting date; the 'White Friendship' cultivar was the exception in terms of total stem length, for the second date.

No local effect was observed on the first planting date for PL-R2 duration (Table 1), spike length (Table 2 ) and stem length (Table 3). However, on the second planting date, a stronger local effect was noted for spike length and stem length, mainly in the cultivars of 'Gold Field', 'Jester', 'Rose Friendship' and 'White Friendship', which registered the lowest values, mostly in Itaqui. No site effect for both variables was reported for the 'Gold Field' and 'Rose Friendship' cultivars on the third planting date. However, the local effect was observed in the stem length for the cultivars of 'Green Star', 'Purple Flora', and 'White Friendship', recording higher values in Santa Maria; with respect to spike length, local effect was reported only for the 'Jester' cultivar, which reported higher values in Santa Maria and with no difference from Itaqui.

The stem length for the three planting dates varied less at Santa Maria than at the other sites (Table 3), most likely because of the insufficient supplementary irrigation in
Itaqui and Frederico Westphalen; therefore, this may have caused periods of water deficit, particularly on the second and third planting dates. The pre-flowering and flowering stages are the crucial phases at which the gladiolus plants are more highly sensitive to water deficit. This may have affected the development and final product, causing the reduced plant height and stem size (CARVALHO et al., 2001; PEREIRA et al., 2009).

The decrease in duration of the PL-R2 phase in Frederico Westphalen on the second planting date (29/08) when compared with the third planting date (23/10) must be noted. Early plantings are normally expected to last longer, but the high temperatures (up to $36^{\circ} \mathrm{C}$ ) observed in September and October probably speeded up the development process (STRECK et al., 2012). Besides, on the third planting date a period of low rainfall was observed (accumulated rain 331 $\mathrm{mm}$ ), which induced water deficit and probably prolonged the cycle (CARVALHO et al., 2001).

Stem diameter (Table 4) was influenced by the cultivation site only for the first planting date. At this date, a substantial difference was noted among the cultivars 'Jester', 'Purple Flora' and 'Rose Friendship', which showed higher diameters in Frederico Westphalen. However, no stem diameter measurement was lower than the minimum specified for each class. These results reveal that this quantitative aspect of stem quality is affected only to a minimum degree by the environment compared with the characteristics like spike length and stem length. 
Table 3. Stem length $(\mathrm{cm})$ of the six gladiolus cultivars for three planting dates $(\mathrm{mm} / \mathrm{dd})$ in three locations in Rio Grande do Sul/Brazil: Frederico Westphalen (FW), Itaqui (IT) and Santa Maria (SM) in 2014.

\begin{tabular}{|c|c|c|c|c|c|c|c|}
\hline \multirow[b]{2}{*}{ Site } & \multirow[b]{2}{*}{$\begin{array}{c}\text { Planting } \\
\text { date }\end{array}$} & \multicolumn{6}{|c|}{ Cultivars } \\
\hline & & Gold Field & Green Star & Jester & $\begin{array}{l}\text { Purple } \\
\text { Flora }\end{array}$ & $\begin{array}{c}\text { Rose } \\
\text { Friendship }\end{array}$ & $\begin{array}{c}\text { White } \\
\text { Friendship }\end{array}$ \\
\hline & $08 / 05$ & $104.4 \mathrm{Ba} A^{(1)}$ & $117.5 \mathrm{ABa} A$ & $116.3 \mathrm{ABa} A$ & $116.5 \mathrm{ABa} A$ & $108.9 \mathrm{ABa} A$ & $121.5 \mathrm{Aa} A$ \\
\hline \multirow[t]{3}{*}{ FW } & $08 / 29$ & $98.9 \mathrm{Ba} B$ & $116.9 \mathrm{Aa} A$ & 115.9Aab $A$ & $108.7 \mathrm{ABa} A$ & $102.8 \mathrm{ABa} A$ & $114.2 \mathrm{Aa} A$ \\
\hline & $10 / 23$ & $-(2)$ & $98.7 \mathrm{ABb} B$ & $99.6 \mathrm{Ab} A$ & $88.7 \mathrm{ABb} B$ & $83.2 \mathrm{Bb} A$ & $89.0 \mathrm{ABb} B$ \\
\hline & $07 / 28$ & $105.8 \mathrm{Ba} A$ & $115.4 \mathrm{ABa} A$ & $112.6 \mathrm{Ba} A$ & $112.2 \mathrm{Ba} A$ & $111.1 \mathrm{Ba} A$ & $131.2 \mathrm{Aa} A$ \\
\hline \multirow[t]{3}{*}{ IT } & $09 / 22$ & $89.2 \mathrm{ABa} B$ & $96.8 \mathrm{Ab} A$ & $90.5 \mathrm{Ab} B$ & $91.1 \mathrm{Ab} B$ & $79.0 \mathrm{Bb} B$ & $78.5 \mathrm{Bb} B$ \\
\hline & $10 / 26$ & $97.9 \mathrm{Aa} B$ & $91.7 \mathrm{Ab} B$ & 99.6Aab $A$ & 89.7AbB & $83.3 \mathrm{Ab} A$ & $94.8 \mathrm{Ab} A B$ \\
\hline & $07 / 31$ & $107.4 \mathrm{Bb} A$ & $119.5 \mathrm{ABa} A$ & $120.9 \mathrm{ABa} A$ & $116.6 \mathrm{ABa} A$ & $116.8 \mathrm{ABa} A$ & $127.6 \mathrm{Aa} A$ \\
\hline \multirow[t]{2}{*}{ SM } & $09 / 23$ & $126.9 \mathrm{Aa} A$ & $120.4 \mathrm{ABa} A$ & $120.1 \mathrm{ABa} A$ & $111.5 \mathrm{ABa} A$ & $105.7 \mathrm{Bab} A$ & $114.4 \mathrm{ABab} A$ \\
\hline & $10 / 27$ & 117.6Aab $A$ & $116.7 \mathrm{Aa} A$ & $111.4 \mathrm{ABa} A$ & $107.9 \mathrm{ABa} A$ & $95.4 \mathrm{Bb} A$ & $108.1 \mathrm{ABb} A$ \\
\hline
\end{tabular}

(1) Upper case letters indicate a comparison of the various cultivars in the row within each planting date for each site. Lower case letters enable the comparison of the cultivars in the column, at the planting dates, in each site. Italic upper case letters compare the same cultivar in the column, on the same planting date of the cultivars at the three different locations. Means followed by the same letter do not differ according to the Tukey test at $5 \%$ error. $\mathrm{CV}=5,28 \%$.

${ }^{(2)}$ No data are available for this cultivar on this planting date and cultivation site.

Table 4. Stem diameter $(\mathrm{cm})$ of the six gladiolus cultivars for three planting dates $(\mathrm{mm} / \mathrm{dd})$ in three locations in Rio Grande do Sul/ Brazil: Frederico Westphalen (FW), Itaqui (IT) and Santa Maria (SM) in 2014.

\begin{tabular}{|c|c|c|c|c|c|c|c|}
\hline \multirow[b]{2}{*}{ Site } & \multirow[b]{2}{*}{$\begin{array}{c}\text { Planting } \\
\text { date }\end{array}$} & \multicolumn{6}{|c|}{ Cultivars } \\
\hline & & Gold Field & Green Star & Jester & $\begin{array}{c}\text { Purple } \\
\text { Flora }\end{array}$ & $\begin{array}{c}\text { Rose } \\
\text { Friendship }\end{array}$ & $\begin{array}{c}\text { White } \\
\text { Friendship }\end{array}$ \\
\hline & $08 / 05$ & $1.14 \mathrm{Ba} A^{(1)}$ & $1.12 \mathrm{ABa} A$ & $1.31 \mathrm{Aa} A$ & $1.20 \mathrm{ABa} A$ & $1.12 \mathrm{Ba} A$ & $1.18 \mathrm{ABa} A$ \\
\hline \multirow[t]{3}{*}{ FW } & $08 / 29$ & $0.99 \mathrm{Aa} A$ & $1.01 \mathrm{Ab} A$ & $1.11 \mathrm{Ab} A$ & $1.06 \mathrm{Aab} A$ & $1.04 \mathrm{Aab} A$ & $1.08 \mathrm{Aa} A$ \\
\hline & $10 / 23$ & $-(2)$ & $1.03 \mathrm{Ab} A$ & $1.06 \mathrm{Ab} A$ & $0.96 \mathrm{Ab} A$ & $0.94 \mathrm{Ab} A$ & $1.05 \mathrm{Aa} A$ \\
\hline & $07 / 28$ & $1.01 \mathrm{Aa} A$ & $1.12 \mathrm{Aa} A$ & $1.14 \mathrm{Aa} B$ & $1.07 \mathrm{Aa} A B$ & $1.04 \mathrm{Aa} A B$ & $1.12 \mathrm{Aa} A$ \\
\hline \multirow[t]{3}{*}{ IT } & $09 / 22$ & $0.99 \mathrm{Aa} A$ & $1.01 \mathrm{Aab} A$ & $1.05 \mathrm{Aab} A$ & $1.01 \mathrm{Aa} A$ & $0.90 \mathrm{Aa} A$ & $0.95 \mathrm{Ab} A$ \\
\hline & $10 / 26$ & $1.00 \mathrm{Aa} A$ & $0.88 \mathrm{Ab} A$ & $0.95 \mathrm{Ab} A$ & $1.05 \mathrm{Aa} A$ & $0.92 \mathrm{Aa} A$ & $1.07 \mathrm{Aab} A$ \\
\hline & $07 / 31$ & $1.03 \mathrm{Ba} A$ & $1.09 \mathrm{ABa} A$ & $1.2 \mathrm{Aa} A B$ & $1.02 \mathrm{Ba} B$ & $0.95 \mathrm{Ba} B$ & $1.10 \mathrm{ABa} A$ \\
\hline \multirow[t]{2}{*}{ SM } & $09 / 23$ & $0.99 \mathrm{ABa} A$ & $1.00 \mathrm{ABa} A$ & 1.10Aab $A$ & $0.96 \mathrm{ABa} A$ & $0.91 \mathrm{Ba} A$ & $0.98 \mathrm{ABa} A$ \\
\hline & $10 / 27$ & $0.97 \mathrm{ABa} A$ & $0.97 \mathrm{ABa} A$ & $1.01 \mathrm{ABb} A$ & $1.01 \mathrm{ABa} A$ & $0.90 \mathrm{Ba} A$ & $1.07 \mathrm{Aa} A$ \\
\hline
\end{tabular}

(1) Upper case letters indicate a comparison of the various cultivars in the row within each planting date for each site. Lower case letters enable the comparison of the cultivars in the column, at the planting dates, in each site. Italic upper case letters compare the same cultivar in the column, on the same planting date of the cultivars at the three different locations. Means followed by the same letter do not differ according to the Tukey test at $5 \%$ error. $\mathrm{CV}=5,25 \%$. (2) No data are available for this cultivar on this planting date and cultivation site.

The early and intermediate varieties cultivated at the three growing sites revealed spike length, stem length and stem diameter well within the criteria of 'Veiling Holambra', for all the planting dates. The planting dates selected in this study corresponded with the ideal times for cultivation of the gladiolus crop in Rio Grande do Sul, i.e. July, August and September (SCHWAB et al., 2015b). These are the months when damages due to high air temperature or solar radiation are minimal.

For the 'Green Star', 'Jester', 'Purple Flora', 'Rose Friendship' and 'White Friendship' cultivars, $44.4 \%$ of the stems were classified as Class 110, particularly the ones 
cultivated on the first planting date for all the three sites. The same cultivars showed $40.0 \%$ being categorized in Class 90 and $15.6 \%$ in Class 75 . Therefore, it is evident that the more the planting date is delayed, the greater the drop in the classes, for all the three sites (Figure 4); the exception to this were the cases of 'Jester' and 'Rose Friendship', which maintained the same class for all the three planting dates in Santa Maria, at 110 and 90, respectively. For the later planting dates (second and third dates), the air temperatures were higher, which probably induced the decrease in stem sizes (SCHWAB et al., 2015b).
In a similar study realized by Schwab et al., (2015b) in Santa Maria during 2012-2013, 54.7\% of the cases the floral stems of 'Jester', 'Amsterdam', 'Rose Friendship' and 'Peter Pears' cultivars were classified as Class 90 and $31.3 \%$ as Class 110. Furthermore, Schwab et al. (2015b) also verified that the 'Rose Friendship' cultivar when planted in October produce small stems, and this result corroborates with the one found in this work, in which for the three sites the plantations carried out in October presented the same behavior for 'Rose Friendship' cultivar and for early cycle cultivars ('Purple Flora' and 'White Friendship').
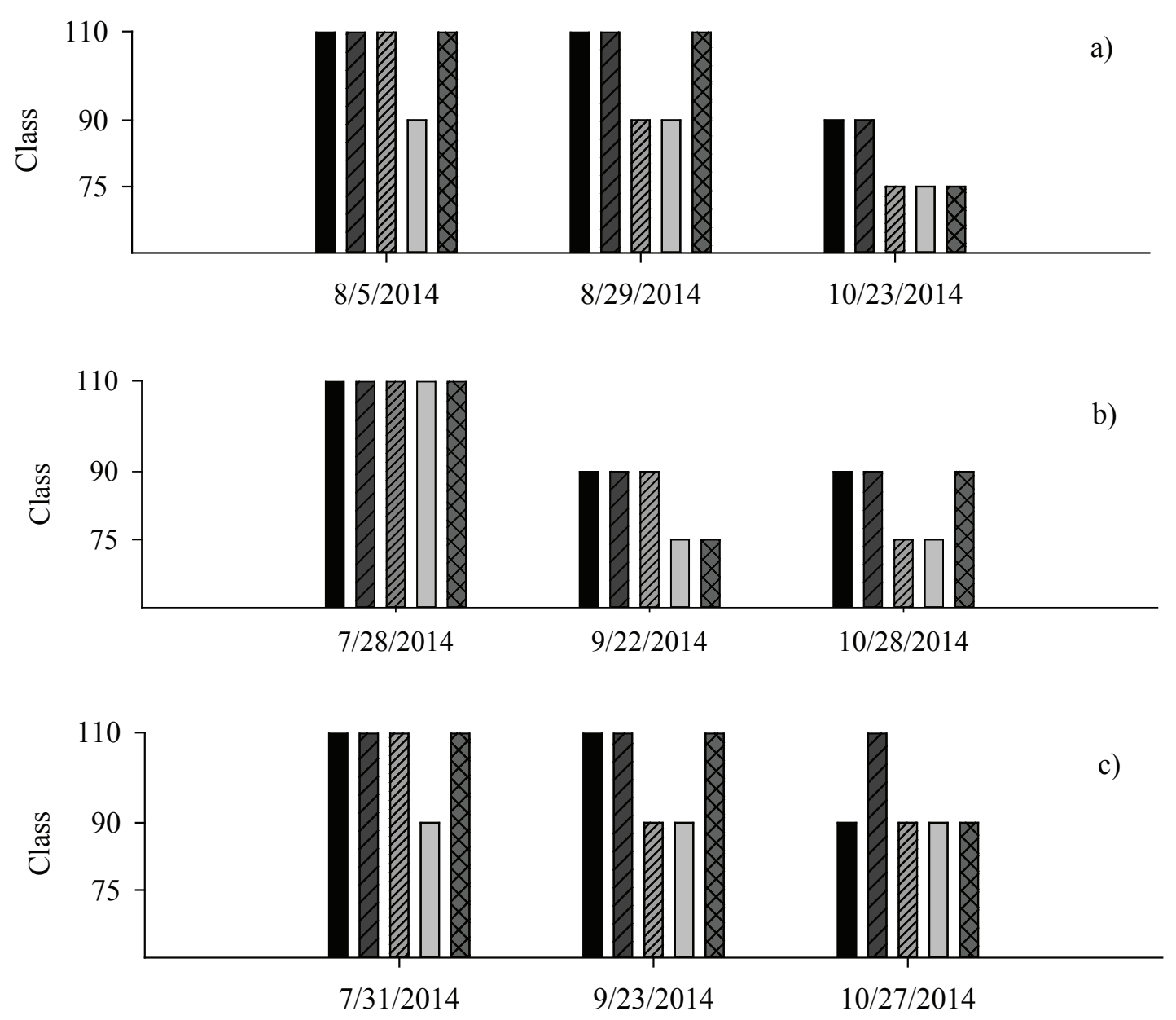

Planting date

Green Star $\square \backslash \square$ Jester $\mathbb{Z I I}$ Purple Flora $\square$ Rose Friendship $\square \times$ White Friendship

Figure 4. The classes of the gladiolus floral stems, according to Veiling Holambra criteria (VEILING HOLAMBRA, 2016), for the cultivars 'Green Star', 'Jester', 'Purple Flora', 'Rose Friendship' and 'White Friendship' in Frederico Westphalen (a), Itaqui (b) and Santa Maria (c) for three planting dates in 2014 ( $\mathrm{mm} / \mathrm{dd} / \mathrm{yyyy}$ ).

The late cultivar, as 'Gold Field', show no compensation in quantitative terms for the longest time period in the field, and so this cultivar is not recommended for any site or planting date. However, the early cycle cultivars ('Purple Flora', 'Rose Friendship' and 'White Friendship') and the intermediates ('Green Star' and 'Jester') had quantitative aspects of stem quality within the standards. The early cycle cultivars revealed a shorter in planting to harvest (PL-R2) in all the planting dates, for the three sites. Therefore, these cultivars are recommended for commercial cultivation in this sites and the introduction of these cultivars into the region of Southern Brazil is suggested. 
When planted in early dates, that occurs lower air temperatures (July and August), the cycle duration is extended for all cultivars, independent the cycle. This result was also found by Schwab et al. (2018), which identified a change in the cycle duration when the planting was carried out in colder months, being prolonged when compared to those grown in the warmer months. The best planting date for these sites is during the second fortnight of July and first fortnight of August for presenting the best stems quality for three sites, because none of the cultivation sites was highlighted in relation to the quality stems. A less time in the field is preferable, because the plants are less exposed to biotic and abiotic factors, such as diseases, high temperatures and water deficiency, that can influence the quality of the flowers stems. The chosen of earlier planting date are the most indicated, especially when the producer do not have an irrigation system and because is likely to occur water deficiency.

These results can aid producers in their choice of cultivars for each region, especially those who wish to produce floral stems for a specific date, such as a wedding, which require quality floral stems, within the standards, playing an important role in satisfying the final consumer's demand. Besides that, the production of better quality gladiolus floral stems (Class 90 and Class 110) has high added value to the product and guarantees to the farmers a higher income.

\section{CONCLUSIONS}

It is proved that gladiolus are grown successfully in Southern Brazil and the cycle duration may varies according to the planting date and cultivation site. The duration of the planting-harvest phase in days, varies from 71 days for the early cultivars ('Rose Friendship', 'Purple Flora' and 'White Friendship') to 87 days for the late cultivars ('Gold Field'). Despite this variation, the quantitative parameters of floral stems of gladiolus cultivated in Rio Grande do Sul/ Brazil were within the standards of quality established by the main sales player i.e. 'Veiling Holambra'.

\section{AUTHORS CONTRIBUTION}

R.T. (D0000-0001-5498-3645: work conception, data collection, analysis and interpretation, writing and critical review of article. G.M.P. D0000-0003-4644-4005: work supervisor, work conception, data collection, analysis and interpretation, writing and critical review of article. N.A.S. D0000-0002-2495${ }^{0823}$ : work supervisor, work conception, data collection, analysis and interpretation, writing and critical review of article. L.O.U. (D0000-0001-9142-4201: data collection, analysis and interpretation, essay writer. C.C.B. D0000-0001-6155-6457: data collection, analysis and interpretation, essay writer. N.T.S. (D)0000-0003-4767-2907: data collection, analysis and interpretation, writing and critical review of article. M.M. D0000-0003-1033-6790: data collection, analysis and interpretation, essay writer. C.M.A. (D0000-0003-2496-5272: data collection, analysis and interpretation, writing and critical review of article.

\section{REFERENCES}

ADIL, M.; AHMAD, W.; AHMAD, K.S.; SHAFI, J.; SHEHZAD, M.A.; SARWAR, M.A.; SALMAN, M.; GHANI, M.I.; IQABAL, M. Effect of different planting dates oh growth as development of Gladiolus Grandiflorus under the ecological conditions of Faisalabab, Pakistan. Universal Journal of Agricultural Research, v.1, n.3, p.110-117, 2013. DOI: 10.13189/ujar.2013.010311

AHMAD, T.; AHMAD, I.; QASIM, M. Present status and future prospects of gladiolus cultivation in Punjab, Pakistan. Journal of Tekirdag Agricultural Faculty, v.5, n.3, p.227-238, 2008.

ALBUQUERQUE, A.W. DE; ROCHA, E.S.; COSTA, J.P.V. DA; FARIAS, A.P.; BASTOS, A.L. Produção de helicônia Golden Torch influenciada pela adubação mineral e orgânica. Revista Brasileira de Engenharia Agrícola e Ambiental, v.14, n.10, p.10521058, 2010. DOI: http:// dx.doi.org/10.1590/S1415-43662010001000005

CARVALHO, J.A.; HENRIQUES, E.B.; PAIVA, P.D.O.; PEREIRA, G.M.; PEREIRA, J.R.D. Crescimento e produção de hastes florais de gladíolo cultivado com déficit hídrico nas diferentes fases fenológicas. Revista Brasileira de Horticultura Ornamental, v.7, n.2, p.95100, 2001. DOI: http://dx.doi.org/10.14295/rbho.v7i2.84

DWIVEDI, S.K.; ARORA, A.; SINGH, V.P.; SAIRAM, R.P.; BHATTACHARYA, R.C. Effect of sodium nitroprusside on differential activity of antioxidants and expression of SAGs in relation to vase life of gladiolus cut flowers. Scientia Horticulturae, v.210, p.158-165, 2016. DOI: doi.org/10.1016/j.scienta.2016.07.024

INTERNATIONAL FLOWER BULB CENTRE. Gladiolus as Cut Flowers: Guidelines for Cut Flower Production, 2011. <www.steenvoorden.nl\%2Fbestanden\%2FGrowing Gladioli_Cutflower_28English_29.pdf\&usg=AOvVaw3eb kqrJcyIKGeTDOflq $\overline{5 w S}>$. Acessed in 2018, September 26.

LIM, T. K. Gladiolus grandiflorus. In: Lim, T. K. Edible Medicinal and Non Medicinal Plants. New York: Springer, 2014. p.144-150.

PEREIRA, J.A.D.; CARVALHO, J.A.; PAIVA, P.D.O.; SILVA, D.J.; SOUZA, A.M.G.; SOUZA, K.J. Crescimento e produção de hastes florais de gladíolo cultivado sob diferentes tensões de água no solo. Ciência e Agrotecnologia, v.33, n.4, p.965-970, 2009. DOI: dx.doi. org/10.1590/S1413-70542009000400004

SALEEM, M.; AHMAD, I.; KHAN, M.A. Cultivar effects on growth, yield and cormel production of gladiolus (Gladiolus grandiflorus L.). Journal of Ornamental and Horticultural Plants, v.3, n.1, p.39-48, 2013. 
SCHWAB, N.T.; STRECK, N.A.; BECKER, C.C.; LANGNER, J.A.; UHLMANN, L.O.; RIBEIRO, B.S.M.R. A phenological scale for the development of Gladiolus. Annals of Applied Biology, v.166, p.496-507, 2015a. DOI: dx.doi.org/10.1111/aab.12198

SCHWAB, N.T.; STRECK, N.A.; RIBEIRO, B.S.M.R.; BECKER, C.C.; LANGNER, J.A.; UHLMANN, L.O.; RIBAS, G.G. Parâmetros quantitativos de hastes florais de gladíolo conforme a data de plantio em ambiente subtropical. Pesquisa Agropecuária Brasileira, v.50, n.10, p.902-911, 2015b. DOI: dx.doi.org/10.1590/S0100204X2015001000006

SCHWAB, N.T.; STRECK, N.A.; UHLMANN, L.O.; BECKER, C.C.; RIBEIRO, B.S.M.R.; LANGNER, J.A.; TOMIOZZO, R. Duration of cycle and injuries due to heat and chilling in gladiolus as a function of planting dates. Ornamental Horticulture, v.24, n.2, p.163-173, 2018. DOI: doi.org/10.14295/oh.v24i2.1174

SEVERINO, C.A.D.M. Cultivo comercial de Palma de Santa Rita (Gladiolus sp. Tourm.). Brasília: Ibict, Serviço Brasileiro de Respostas Técnicas; Salvador: Rede de Tecnologia da Bahia, 2007. 22p.

SHILLO, R.; HAVELY, A.H. The effect of various environmental factors on flowering of gladiolus. I. Light intensity. Scientia Horticulturae, v.4, n.2, p.131-137, 1976a. DOI: doi.org/10.1016/S0304-4238(76)80004-0

SHILLO, R.; HAVELY, A.H. The effect of various environmental factors on flowering of gladiolus. II. Length of the day. Scientia Horticulturae, v.4, n.2, p.139-146, 1976b. DOI: doi.org/10.1016/S0304-4238(76)80005-2

SHILLO, R.; HAVELY, A.H. The effect of various environmental factors on flowering of gladiolus. III. Temperature and moisture. Scientia Horticulturae, v.4, n.2, p.147-155, 1976c. DOI: doi.org/10.1016/S03044238(76)80006-4

SHILLO, R.; HAVELY, A.H. The effect of various environmental factors on flowering of gladiolus. IV. Interaction of environmental factors - general discussion. Scientia Horticulturae, v.4, n.2, p.157-162, 1976d. DOI: doi.org/10.1016/S0304-4238(76)80007-6
STRECK, E.V.; KÄMPF， N.; DALMOLIN， R.S.D.; KLAMT, E.; NASCIMENTO, P.C.DO; SCHNEIDER, P.; GIASSON, E.; PINTO, L.F.S. Solos do Rio Grande do Sul. Porto Alegre: EMATER/RS. UFRGS, 2008. 126p.

STRECK, N.A.; BELLÉ, R.A.; BACKES, F.A.A.L.; GABRIEL, L.F.; UHLMANN, L.O.; BECKER, C.C. Desenvolvimento vegetativo e reprodutivo em gladíolo. Ciência Rural, v.42, n.11, p.1968-1974, 2012. DOI: dx.doi.org/10.1590/S0103-84782012001100010

TOMBOLATO, A.F.C.; UZZO, R.P.; JUNQUEIRA, A.H.; PEETZ, M.S.; STANCATO, G.C.; ALEXANDRE, M.A.V. Bulbosas ornamentais no Brasil. Revista Brasileira de Horticultura Ornamental, v.16, n.2, p.127-138, 2010. DOI: dx.doi.org/10.14295/rbho.v16i2.553

UHLMANN, L.O.; STRECK, N.A.; BECKAR, C.C.; SCHWAB, N.T.; BENEDETTI, R.P.; CHARÃO, A.S.; RIBEIRO, B.S.M.R.; SILVEIRA, W.B.; BACKES, F.A.A.L.; ALBERTO, C.M.; MUTTONI, M.; PAULA, G.M.; TOMIOZZO, R.; BOSCO, L.C.; BECKER, D. PhenoGlad: A model for simulating development in Gladiolus. European Journal of Agronomy, v.82, p.3349, 2017. DOI: doi.org/10.1016/j.eja.2016.10.001

VASANTHAKUMAR, K.; BEZU, T.; BEKELE, A. Response of varieties and planting dates on growth and flowering of gladiolus (Gladiolus grandiflorus Andrews) under the ecological conditions of Haramaya University, Eastern Ethiopia. Journal of Horticulture and Forestry, v.7, n.5, p.112-117, 2015. DOI: doi.org/10.5897/ JHF2015.0392

VEILING HOLAMBRA. 2016. Critérios de classificação: Gladíolo corte. Departamento de Qualidade e Pós-Colheita, 5p. Disponível em: <http://veiling.com.br/ uploads/padrao/gladiolo-fc.pdf $>$ Acesso em: 11 de março de 2016.

ZUBAIR, M.; WAZIR, F.K.; AKHTAR, S.; AYUB, G. Planting Dates Affect Floral Characteristics of Gladiolus under the Soil and Climatic Conditions of Peshawar. Pakistan Journal of Biological Sciences, v.9, p.16691976, 2006. doi: 10.3923/pjbs.2006.1669.1676. 